\title{
Black Carbon Contents and Distribution in Sediments from the Southeastern Brazilian Coast (Guanabara Bay)
}

\author{
Letícia G. L. Ribeiro, ${ }^{a}$ Renato S. Carreira ${ }^{*, b}$ and Angela L. R. Wagener ${ }^{a}$
}

\author{
${ }^{a}$ Departamento de Química, Pontifícia Universidade Católica do Rio de Janeiro, R. Marquês de São Vicente, 225, \\ 22453-900 Rio de Janeiro-RJ, Brazil
}

${ }^{b}$ Faculdade de Oceanografia, Universidade do Estado do Rio de Janeiro, R. São Francisco Xavier, 524, 20550-013 Rio de Janeiro-RJ, Brazil

\begin{abstract}
As concentrações de black carbon (BC), assim como a contribuição relativa de $\mathrm{BC}$ para o total de carbono orgânico sedimentar, foram determinadas pela primeira vez na Baía de Guanabara. A quantificação de BC realizou-se por método térmico (CTO-375) e a de carbono orgânico por método de oxidação a seco. As concentrações de carbono orgânico apresentaram grande variabilidade entre as estações (0,82 a 10,3\%), mas foi possível definir regiões distintas na Baía de acordo com parâmetros como granulometria do sedimento, localização e magnitude de fontes autóctonas e alóctonas de matéria orgânica e hidrodinamismo. As concentrações de BC foram inesperadamente baixas $(0,03$ a $0,31 \%$, com média de $0,19 \pm 0,07 \%, \mathrm{n}=25)$, levando-se em conta o largo espectro de fontes possíveis, tanto em terra como na água, para essas substâncias. No entanto, em algumas estações o BC estava presente em níveis que podem exercer influência sobre o destino de contaminantes prioritários, tais como HPA e dioxinas. Os resultados mostraram que a distribuição espacial das concentrações de BC na Baía de Guanabara é complexa e não pode ser completamente compreendida no estágio atual de conhecimento, sendo necessárias informações adicionais, tais como fontes de emissão de BC (p.ex., queima de biomassa e consumo de combustíveis) e processos de dispersão de partículas.
\end{abstract}

The concentration of black carbon (BC), as well as the relative contribution of $\mathrm{BC}$ to total organic carbon, was determined for the first time in sediments from Guanabara Bay. BC was quantified by a thermal oxidation method (CTO-375) and total organic carbon by dry oxidation. Sedimentary organic carbon showed a large range in concentrations $(0.82$ to $10.3 \%)$, but it was possible to define distinct regions of the Bay accordingly to variations in sediment grain size, location and magnitude of allochthonous and autochthonous sources of organic matter and hydrodynamic features. Low concentrations of $\mathrm{BC}$ were observed $(0.03$ to $0.31 \%$, with a mean of $0.19 \pm 0.07 \%, \mathrm{n}=25$ ) when considering the large spectrum of possible sources on land and at sea. However, in some stations levels are sufficiently high as to influence the fate of pollutants of concern, such as PAH and dioxins. The space distribution of BC concentrations in Guanabara Bay cannot be fully understood at this stage since further information on contributions from various sources and on natural dispersion processes are required.

Keywords: black carbon, organic carbon, sediments, Guanabara Bay

\section{Introduction}

Black carbon (BC) is the general term applied for the residues of incomplete combustion of organic matter. It represents a continuum of materials with different physical and chemical properties including, in order of increasing resistance to biodegradation, slightly charred biomass,

\footnotetext{
*e-mail: carreira@uerj.br
}

chars and charcoals produced by the burning of vegetation and soot produced from fossil fuels consumption. ${ }^{1-3}$

In fact, the term BC should be considered as an operational measure, since the distinct methodologies used for its determination, based on optical, thermal or chemical properties (or in a combination of them), detect different windows in the $\mathrm{BC}$ continuum and thus data comparison must consider the limitations and bias of each method. ${ }^{4}$ Therefore, BC can also be defined as "a carbonaceous substance of pyrogenic origin, 
which is resistant to thermal or chemical degradation under the conditions applied in the methods" commonly used for its determination (http://www.geo.unizh.ch/phys/bc/, accessed in December 2007). Finally, the term "elemental carbon" is sometimes used interchangeably with $\mathrm{BC}$, but it is more commonly applied in atmospheric science.

$\mathrm{BC}$ is ubiquitous in soils and other terrestrial environments as well as in the atmosphere, and can be found in marine sediments due to river and atmospheric transport. Since BC is relatively resistant to biological and chemical breakdown, it represents a sink for $\mathrm{C}$ in the environment - it may account from 1 to $20 \%$ of the pool of organic carbon in the environment, and can be a major component of riverine carbon exported to the ocean, although the magnitude of this processes is only poorly understood. , $3,5,6^{2,6}$

In the last 20-30 years, the research on BC expanded from the traditional field of atmospheric science to a growing interest in the organic geochemistry of these particles, including sources, transport and accumulation in aquatic systems, and characterization of chemical composition and structure. ${ }^{7,8}$ Such interest draws from the increasing emissions of anthropogenic-derived black carbon originated from agricultural activities and consumption of fossil fuels associated with the complex role of $\mathrm{BC}$ in environmental process. ${ }^{9,10} \mathrm{BC}$ particles may contribute to global warming through absorption of solar irradiance and decrease of Earth's albedo when present in polar ice sheets, and may be a carrier for carcinogenic contaminants with possible health effects. ${ }^{3,11}$ On the other hand, BC can reduce bioavailability of contaminants such as PAH, PCBs, dioxins and PDBEs through strong sorption which can fundamentally control uptake and the effective toxicity of these chemicals in aquatic systems. ${ }^{1,10}$

In this work we present the first report on the distribution of BC in sediments of Guanabara Bay and evaluate the relative $\mathrm{BC}$ contribution to the pool of sedimentary organic carbon. Guanabara Bay is a complex coastal system, circumscribed by the City of Rio de Janeiro and other municipalities (Figure 1). Previous studies conducted in the region allow a fairly good characterization of water, sediments and biota contamination by organic and inorganic residues, although none of these studies has addressed the issue of black carbon as a potential contaminant in the bay. ${ }^{12-17}$

\section{Experimental}

\section{Study area and sampling procedures}

Guanabara Bay (see Figure 1) is located at $22^{\circ} 40^{\prime}-23^{\circ}$ $00^{\prime} \mathrm{S}$ latitude and $43^{\circ} 00^{\prime}-43^{\circ} 18^{\prime} \mathrm{W}$ longitude and occupies an area of $346 \mathrm{~km}^{2}$ with a volume of around $2.2 \times 10^{9} \mathrm{~m}^{3}$ and a mean water depth of $7.7 \mathrm{~m} .{ }^{18}$ The hydrographic basin extending over $4.080 \mathrm{~km}^{2}$ includes 45 rivers, six of which are responsible for $85 \%$ of the runoff $\left(100 \pm 59 \mathrm{~m}^{3} \mathrm{~s}^{-1}\right)$. The mean half-water volume renewal time is 11.4 days, although in some parts of the bay this time is significantly higher. ${ }^{14}$

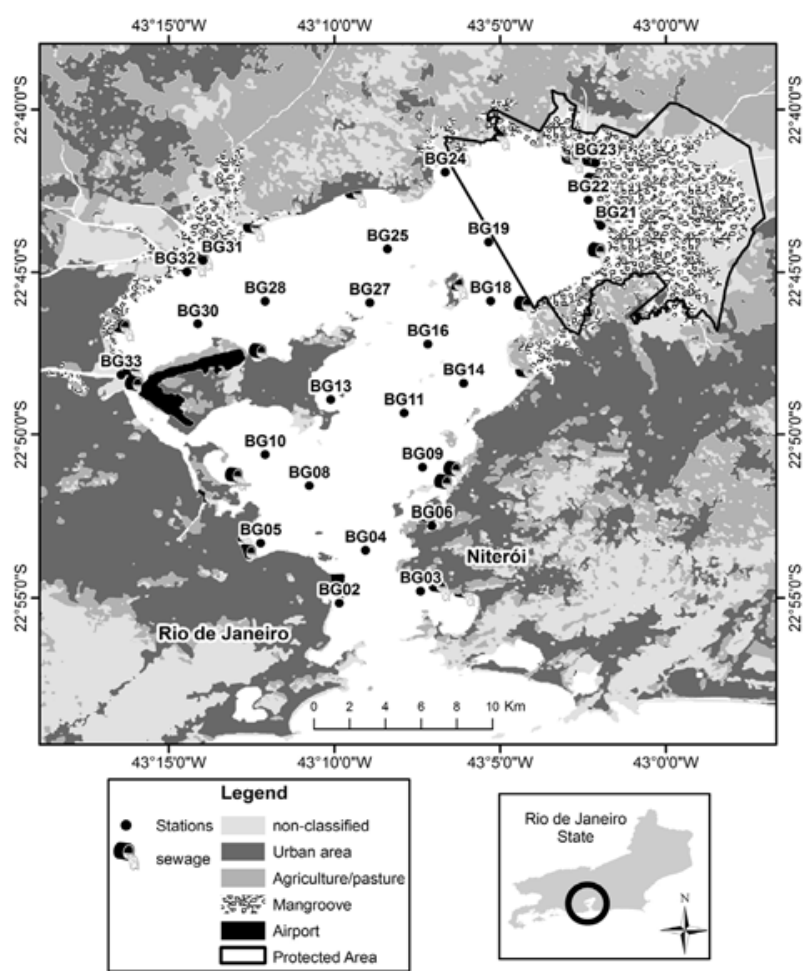

Figure 1. General view of Guanabara Bay region and the sampling stations.

Sediments in the bay comprised of sand, muddy-sand, sandy-mud and mud are spatially distributed in response to bottom topography, shoreline configuration, tidal currents and sediment sources. ${ }^{19}$ Coarse and medium sands are predominant at the entrance of the bay and in the central channel extending northwards up to Governador Island. Extensive mud and fine sands deposits resulting from the active transport of clastic material and flocculated clays are found in the north area of the bay. ${ }^{14}$ Mangroves are very important sources of sediments in the northeastern area. In the north-western and western part of the bay, sediment inputs are substantial and the area is highly influenced by anthropogenic activities (e.g. sewage inputs, channeling of rivers and deforestation for urban settlement and agriculture).

Sediments were collected in July 2005 from 25 stations (Figure 1) by scuba-diving and using a small metallic corer. The top $2 \mathrm{~cm}$ of the sediment column were carefully subsampled and stored in pre-combusted and solvent rinsed aluminum boxes. Samples were kept in ice during field work and stored at $-20^{\circ} \mathrm{C}$ in the laboratory. Before analysis, samples were freeze dried and pulverized $(<63 \mu \mathrm{m})$. 


\section{Organic carbon and total nitrogen determination}

Total organic carbon (TOC) and total nitrogen (TN) were analyzed in duplicate in a Carlo Erba EA 1110 elemental analyzer. Sediment samples were precisely weighed (2-5 mg; $\pm 0.01 \mathrm{mg}$ ) on silver capsules. Hydrochloric acid $\left(1.2 \mathrm{~mol} \mathrm{~L}^{-1}\right)$ was added directly to the capsules for inorganic carbon removal. ${ }^{20}$ Quantification was performed by using calibration curves ( $r>0.999)$ and cystine as standard. Precision was $\pm 3.9 \%$ for TOC and $\pm 7.4 \%$ for $\mathrm{TN}$, based on the coefficient of variation of replicate analysis $(n=10)$ of a reference material (PACS-2/NRCC). The mean TOC concentration $(4.1 \pm 0.1 \% ; n=4)$ found for a standard sediment sample (NIST SRM-1944) was within the expected range for the certified value $(4.4 \pm 0.3 \%)$. Limit of quantification was calculated as $0.03 \%$ for TOC and $0.01 \%$ for TN.

\section{Black carbon determination}

The determination of black carbon was based on the thermal oxidation method (CTO-375). ${ }^{21}$ Sub-samples of about $10 \mathrm{mg}$ were weighted (precision of $\pm 0.01 \mathrm{mg}$ ) directly into silver capsules, treated with $\mathrm{HCl}$ as described for TOC analysis and heated using the following temperature program: $10^{\circ} \mathrm{C} \mathrm{min}{ }^{-1}$ up to $300{ }^{\circ} \mathrm{C}, 1^{\circ} \mathrm{C} \mathrm{min}{ }^{-1}$ up to $375 \pm 5^{\circ} \mathrm{C}$, and hold at this temperature for 24 hours. A constant air flux was maintained through the furnace. After the thermal treatment, the residual carbon in the samples (i.e., the black carbon content) was determined as described above for TOC analysis.

The method was checked for accuracy and precision using standard sediment (NIST 1941b). Although this standard is not certified for black carbon content, it was used in international calibration exercises (http://www. geo.unizh.ch/phys/bc/, accessed in December 2007). The $\mathrm{BC}$ found in the present work $(\mathrm{BC}=0.44 \pm 0.03 \%$; $\mathrm{n}=14$ ) was statistically similar (Student's test of similarity) to the value reported in this intercalibration exercise using the CTO-375 method $(\mathrm{BC}=0.53 \pm 0.14 \% ; \mathrm{n}=5)$.

\section{Results and Discussion}

Total organic carbon and $C / N$ ratio of the sedimentary organic matter

Sediments from Guanabara Bay showed a wide range of organic carbon concentrations $(0.82 \%<\mathrm{TOC}<10.6 \%$; Table 1), which is consistent with results from other studies. ${ }^{13,15,16}$ TOC concentrations higher than 5.2\% (Figure $2 \mathrm{~A})$ were measured in the northern (BG18, BG25, BG27 and BG28) and western (BG05, BG10 and BG33) sectors of the bay and concurred with the predominance of fine grained sediments in these areas (Table 1), the restricted water circulation (specially in the western sector),${ }^{14}$ the high sedimentation rates of up to $2.2 \mathrm{~cm}$ per year and the location of autochthonous and allochthonous inputs of organic matter. ${ }^{15,13,22}$ TOC concentrations in the range of 4.0-5.0\% were present in stations BG30, BG31 and BG32 (Figure 2A), despite their proximity to stations BG28 and BG33 which are subjected to factors favoring accumulation of organic carbon. Carreira et al. ${ }^{16}$ found a similar result and pointed out that this would be derived from 'dilution' caused by deposition of inorganic particulates transported by Iguaçu and Sarapuí rivers. Further discussion on the distribution and nature of organic matter in Guanabara Bay will be provided below. TOC concentrations are highly correlated with TN concentrations $(\mathrm{r}=0.95, \mathrm{p}<0.0001)$ and the slope of the regression line close to zero (data not shown) indicates that organic nitrogen is the major component of the total nitrogen.

In addition to differences in TOC concentrations, the nature of organic matter also varies from site to site. The enriched-organic carbon sediments in the north-western region (BG28, $\mathrm{BG} 30, \mathrm{BG} 31, \mathrm{BG} 32$ and $\mathrm{BG} 33$, the latter with the highest measured concentration of TOC) show organic carbon accumulation rates of $458 \mathrm{gC} \mathrm{m}^{-2}$ per year. ${ }^{16}$ Carreira et al. ${ }^{16}$ report that a significant fraction of the total organic carbon in this region derives from sewage reaching the bay through polluted rivers which carry 130 ton day ${ }^{-1}$ of BOD. ${ }^{17,18}$ In the same region, local primary production is low due to restricted light availability. ${ }^{15}$ TOC/TN molar ratios for the stations in the north-western sector of the bay are in the range of 9.4 to 12.9 (Table 1). All these evidences suggest that in the north-western sector of the bay the inputs of sewage and terrestrial/riverine organic carbon are significant sources to the total organic matter pool.

Stations BG08, BG10, BG25 and BG27 have also relatively high TOC concentrations (Figure $2 \mathrm{~A}$ ), but the TOC/TN ratio (Figure 2B) indicated higher influence of autochthonous organic matter. This is consistent with the lipid biomarker distribution obtained in previous work, and can be explained by higher primary productivity favored by euthrophic conditions and enhanced water transparency, although some influence of allochthonous materials transported by tidal currents cannot be discarded. ${ }^{16}$

The TOC concentration of $6.6 \%$ in BG05 is among the highest measured in the bay and probably derived from anthropogenic sources, since this station is in the harbor of Rio de Janeiro and receives high input of sewage through the Mangue channel (Carreira, R., unpublished data). BG06 although also located near to a commercial and industrial harbor shows very low TOC concentration 
Table 1. Concentrations of total organic carbon (TOC), total nitrogen (TN), total organic carbon/total nitrogen ratio (TOC/TN), black carbon (BC), black carbon/total organic carbon ratio (BC/TOC) and sediment type for each station collected in Guanabara Bay in July, 2005

\begin{tabular}{|c|c|c|c|c|c|c|}
\hline Station & $\mathrm{TOC} /(\%)$ & $\mathrm{TN} /(\%)$ & $(\mathrm{TOC} / \mathrm{TN}) /\left(\mathrm{mol} \mathrm{L}^{-1}\right)$ & $\mathrm{BC} /(\%)$ & $(\mathrm{BC} / \mathrm{TOC}) /(\%)$ & sediment type* \\
\hline BG02 & 3.07 & 0.35 & 10.10 & 0.22 & 7.08 & very fine sand/very coarse silt \\
\hline BG03 & 1.22 & 0.20 & 7.11 & 0.09 & 7.70 & moderatelly well sorted medium sand \\
\hline BG04 & 2.36 & 0.29 & 9.62 & 0.12 & 5.05 & coarse silt \\
\hline BG05 & 6.33 & 0.68 & 10.92 & 0.15 & 2.45 & very fine sandy coarse silt \\
\hline BG06 & 0.82 & 0.07 & 12.87 & 0.03 & 4.21 & medium silt \\
\hline BG08 & 4.69 & 0.59 & 9.21 & 0.22 & 4.67 & very fine sandy medium silt \\
\hline BG09 & 1.01 & 0.11 & 10.48 & 0.03 & 2.51 & medium silt \\
\hline BG10 & 6.06 & 0.78 & 9.01 & 0.25 & 4.17 & coarse silt \\
\hline BG11 & 1.36 & 0.16 & 9.91 & 0.18 & 12.75 & coarse silt \\
\hline BG13 & 2.06 & 0.27 & 8.90 & 0.19 & 9.17 & coarse silt \\
\hline BG14 & 4.94 & 0.61 & 9.47 & 0.15 & 3.06 & medium silt \\
\hline BG16 & 4.69 & 0.58 & 9.37 & 0.31 & 6.51 & very fine sandy coarse silt \\
\hline BG18 & 5.34 & 0.66 & 9.38 & 0.27 & 5.05 & medium silt \\
\hline BG19 & 4.48 & 0.53 & 9.88 & 0.22 & 4.93 & coarse silt \\
\hline BG21 & 2.90 & 0.22 & 15.57 & 0.27 & 9.37 & medium silt \\
\hline BG22 & 4.86 & 0.37 & 15.14 & 0.16 & 3.31 & fine silt \\
\hline BG23 & 1.60 & 0.14 & 13.41 & 0.10 & 6.40 & very fine sandy very coarse silt \\
\hline BG24 & 4.20 & 0.39 & 12.62 & 0.28 & 6.72 & very fine sandy very coarse silt \\
\hline BG25 & 5.19 & 0.66 & 9.20 & 0.26 & 4.93 & very fine sandy very coarse silt \\
\hline BG27 & 5.17 & 0.68 & 8.90 & 0.26 & 4.93 & very fine sandy coarse silt \\
\hline BG28 & 5.26 & 0.65 & 9.36 & 0.23 & 4.34 & very fine sandy very coarse silt \\
\hline BG30 & 4.99 & 0.61 & 9.48 & 0.22 & 4.37 & very fine sandy coarse silt \\
\hline BG31 & 4.68 & 0.42 & 12.89 & 0.18 & 3.89 & coarse silt \\
\hline BG32 & 4.02 & 0.44 & 10.67 & 0.16 & 3.90 & medium silt \\
\hline BG33 & 10.60 & 1.04 & 11.93 & 0.25 & 2.32 & coarse silt \\
\hline
\end{tabular}

*Unpublished data from internal report from CENPES/PETROBRAS (authors: Figueiredo, A. G and Cordeiro, R. C.).

$(<1.6 \%)$ possibly reflecting large space heterogeneity in sediment properties and contamination in the area. In these two stations (BG05 and BG06) the TOC/TN ratio lays between 10.92 and 12.87 (Table 1), indicating a mixture of autochthonous and allochthonous sources of organic matter. ${ }^{23}$

Sediments in the north-eastern sector of Guanabara Bay (BG19, BG21-BG24), although predominantly composed of fine grains show lower values for TOC (Figure 2A) than the north-western sector. This can be expected since the input of contamination by local rivers is less important and primary production is limited by turbidity. In fact, TOC/ $\mathrm{TN}$ ratios in most of these stations were in the range of 12-16 (Figure 2B) which suggest the presence of a higher proportion of terrestrial/riverine organic matter. ${ }^{23}$

Some stations in the central channel (BG04 and BG11) and near the entrance of the bay (BG02 and BG03) have lower TOC concentrations (range of $0.82-3.1 \%$; Figure $2 \mathrm{~A}$ ) and the values for the ratio TOC/TN were indicative of mixed sources (Figure 2B). The lower accumulation of organic matter in these stations probably results from the predominance of coarse sediments and effective water mixing by tidal currents.

\section{Distribution of black carbon and its importance relative to TOC}

The BC levels in the studied sediments varied by one order of magnitude ( 0.03 to $0.31 \%$; Table 1 ), with a mean value of $0.19 \pm 0.07 \%(n=25)$. The space distribution of $\mathrm{BC}$ concentrations is shown in Figure 3A. Relatively high concentrations of $\mathrm{BC}(0.26$ to $0.31 \%)$ were present in the central sector of the northern region (BG16, BG18, BG25 and BG27), in station BG10 as well as in stations near to Caceribu (BG21) and Suruí (BG24) Rivers. Based on this distribution one can infer that these two Rivers represent major sources of $\mathrm{BC}$ to the Bay. However, this hypothesis is not consistent with the low contribution of riverine/terrestrial organic matter to sediments deposited relatively distant from the shoreline, as demonstrated by lipid biomarker data. ${ }^{16}$ It must also be considered that other stations, like BG28, BG30 and BG33 in the north-western sector and BG08 and BG02 in the southern part of the Bay, show $\mathrm{BC}$ concentrations in the range of $0.20-0.25 \%$ (Figure 3B), indicating the occurrence of significant sources of $\mathrm{BC}$ to the bay other than Caceribu and Suruí Rivers. 
The most probable source of BC to stations BG16, $\mathrm{BG} 18, \mathrm{BG} 25$ and BG27, which are relatively distant from direct input from rivers, is emission derived from the intense shipping activities associated with oil and gas terminals located southern from these stations. Shortrange atmospheric transport of $\mathrm{BC}$ particles is favored by the prevailing southerly winds in the area during most of the year (Isimar Santos, private communication). On the other hand, in the estuarine region of Caceribu (BG21) and Suruí (BG24) Rivers the BC is probably derived from the anthropogenic activities in the drainage basin, like traffic of small fish boats, and biomass burning in rural areas. Station BG10 is as well relatively enriched in BC (Figure 3A), but
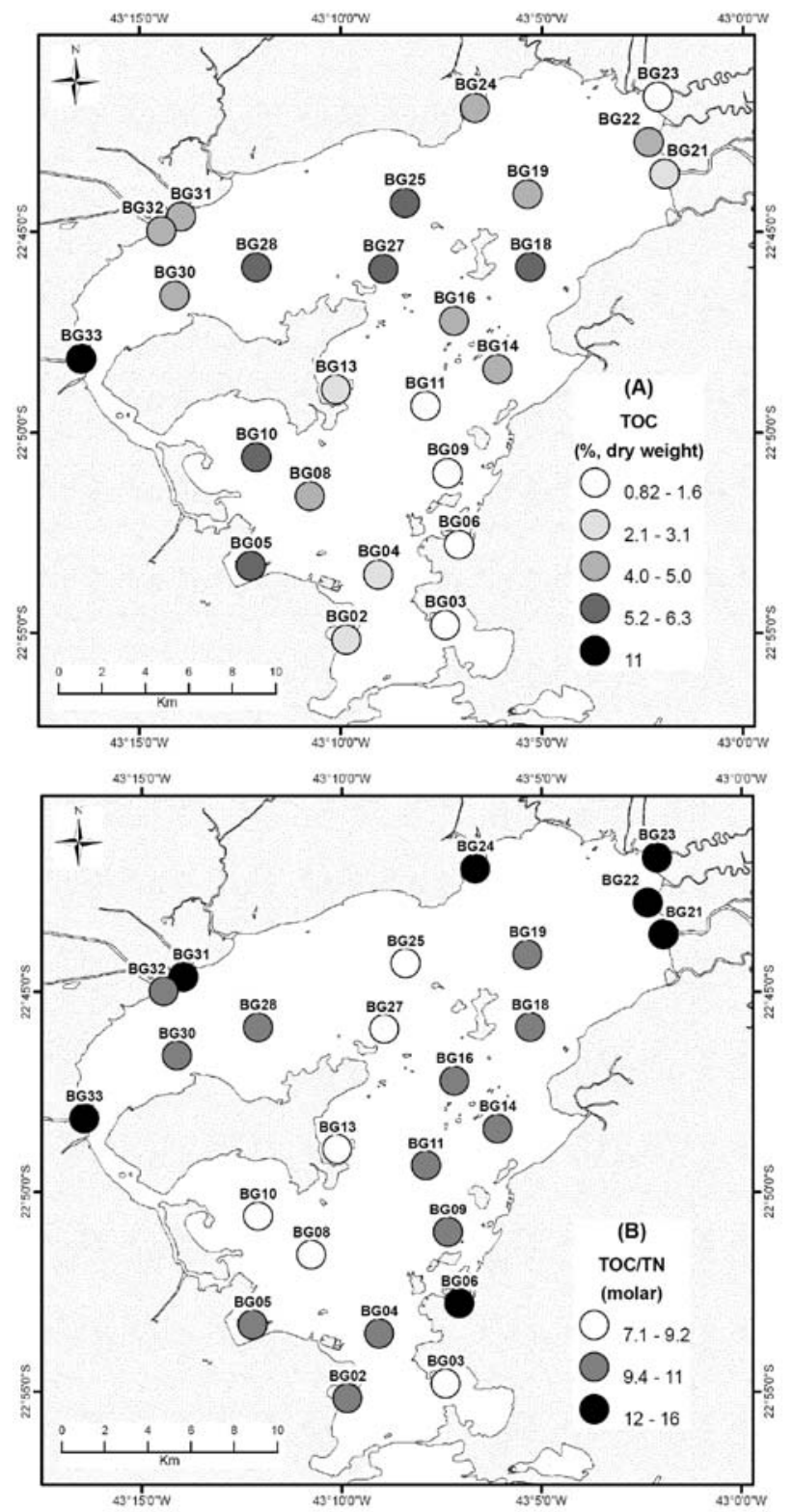

Figure 2. Distribution of (A) total organic carbon (TOC, dry weight \%) and (B) TOC/TN molar ratios in superficial sediments from Guanabara Bay. in this case the source of $\mathrm{BC}$ is probably the transport of particles by tidal currents and subsequent accumulation induced by local hydrodynamic, in a similar way as observed for organic carbon (previously discussed).

The distribution of TOC-normalized concentrations of black carbon, expressed by the ratio BC/TOC, is shown in Figure 3B. It is possible to see in this figure three regions with elevated values for the ratio $\mathrm{BC} / \mathrm{TOC}$, all of them with relatively low organic carbon content. One region comprises stations BG11, BG13 and to a lower extent BG16. These stations are located in the area where ship traffic is intense, similarly as in stations BG16, BG18, BG25 and BG27. In fact, in these latter stations the $\mathrm{BC} / \mathrm{TOC}$ ratio is low (3.9-
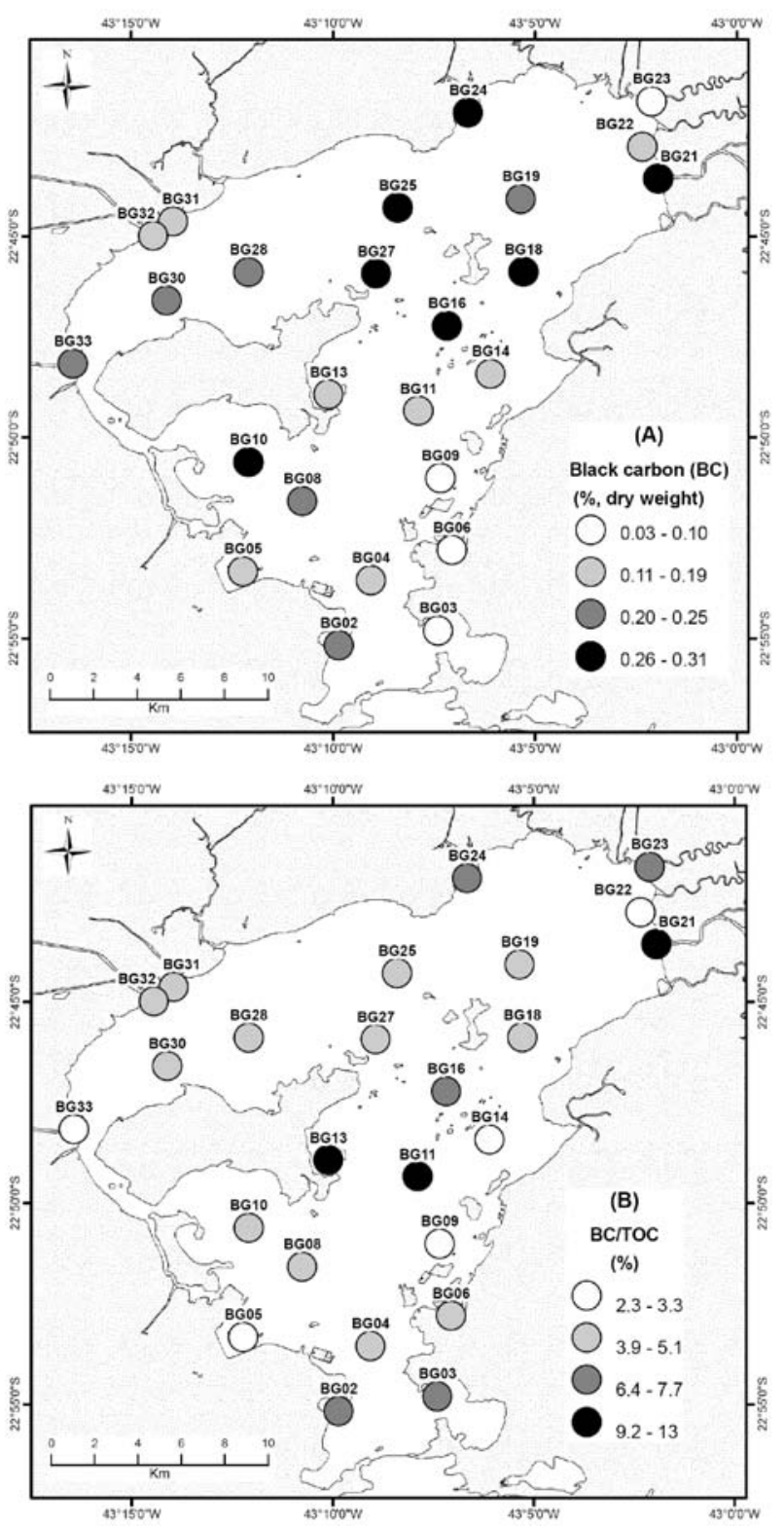

Figure 3. Distribution of (A) black carbon (BC, dry weight \%) and (B) the ratio of $\mathrm{BC}$ to total organic carbon $(\mathrm{BC} / \mathrm{TOC}, \mathrm{x} 100)$ in superficial sediments from Guanabara Bay. 
$5.1 \%$; Figure $3 \mathrm{~B}$ ) due to their high contents of organic carbon. The second group is formed by the stations in the proximity of river mouths in the north-eastern sector (BG21, BG23 and BG24), whose high BC/TOC values are consistent with $\mathrm{BC}$ inputs associated with anthropogenic activities in the drainage basin. A third group of stations with high BC/TOC values is formed by the stations in the embayment near the bay's mouth (BG02 and BG03). In this case, the input of BC might be derived from emissions associated with circulation of small recreational boats, since there are several marinas in the region, as well as it might include, in the case of station BG02, contributions from Santos Dumont Airport and urban traffic from Rio de Janeiro City.

Based on the distribution of BC contents discussed above, both in mass percentage and TOC-normalized values, it seems that the $\mathrm{BC}$ in the central and southern regions of Guanabara Bay derive from "internal" anthropogenic sources (particularly ship transportation), although contributions from atmospheric fallout of particles from continental sources cannot be ruled out. The abundance of mangrove forests and rural activities in the north-eastern region suggests that $\mathrm{BC}$ levels near the mouth of the rivers probably derive from biomass burning in the drainage basins.

Table 2. Concentrations of black carbon (BC) and the percentage of black carbon to TOC (BC/TOC) for superficial sediments from Guanabara Bay and other regions in the world. All values relative to $\mathrm{BC}$ determined by the method of thermal oxidation (CTO-375)

\begin{tabular}{lccc}
\hline Regions & $\mathrm{BC} /(\%)$ & $\begin{array}{c}(\mathrm{BC} / \mathrm{TOC}) / \\
(\%)\end{array}$ & Reference \\
\hline $\begin{array}{l}\text { Guanabara Bay/Brazil } \\
\begin{array}{l}\text { Estuaries and urban lakes } \\
\text { from New England/USA }\end{array}\end{array}$ & $0.03-0.31$ & $2.3-12.8$ & This study \\
$\begin{array}{l}\text { Boston Harbor/USA } \\
\text { Pettaquamscutt River }\end{array}$ & $0.26-0.60$ & $16-18$ & 24 \\
$\begin{array}{l}\text { Estuary/USA } \\
\text { Mississipi River, USA }\end{array}$ & $0.43-0.64$ & - & 26 \\
$\begin{array}{l}\text { New York/New Jersey } \\
\text { Estuaries/USA }\end{array}$ & $0.04-0.78$ & $1.9-28$ & 6 \\
Estuaries from Norway & $0.59-0.77$ & $\sim 12$ & 27 \\
\hline
\end{tabular}

The BC contents in Guanabara Bay sediments may be considered low in comparison to other estuaries or bays located in temperate regions, however $\mathrm{BC} / \mathrm{TOC}$ ratios are in the same range (Table 2). In spite of the low absolute concentrations, the contribution of $\mathrm{BC}$ to the total organic matter is high enough to play a significant role in the distribution of organic contaminants in the sediment. For example, Oen et al. ${ }^{10}$ found that in harbor sediments from Norway with BC/TOC ratio in the range of 6.4 to $12.3 \%$ (similar to those found in many stations in Guanabara Bay) the distribution of PAH was dominated by the presence of BC. Since it is well documented that interaction by sorption to $\mathrm{BC}$ particles reduces bioaccumulation and biodegradation of organic contaminants like polycyclic aromatic hydrocarbons (PAH) and dioxins, ${ }^{5,7,21}$ the results of the present work indicate the need for considering the $\mathrm{BC}$ fraction as a factor controlling the fate and effect of PAH contamination in Guanabara Bay.

\section{Conclusions}

This first survey in surface sediments of Guanabara Bay shows unexpected low concentrations of $\mathrm{BC}$ when considering the large spectrum of possible sources on land and at sea. Because black carbon derives from incomplete combustion and is emitted directly into the atmosphere, deposition in surface waters and sedimentation may occur distant from the production source depending on prevailing atmospheric circulation. Charcoal BC particles measuring few millimeters, emitted during biomass burning, are rapidly removed from the atmosphere; however, sub-micro particles derived from fuel combustion in internal combustion motors or emitted by industrial activities reside months in suspension. In this later case deposition on surface waters may occur distant from the sources. In addition, once on the water surface, particles of less than $50 \mathrm{~nm}$ may be driven away by effective tidal currents, as those in Guanabara Bay, before settling down and the result is a weak BC signal recorded in the sediments. The space distribution of $\mathrm{BC}$ concentrations in Guanabara Bay is too complex to be fully understood at this stage. Additional studies directed to elucidate differences in sources which include biomass and fuel combustion as well as natural dispersion processes are required. Similar distributions and fates will occur for pollutants of concern which are embedded in BC moieties, such as combustion derived $\mathrm{PAH}$ and dioxins.

\section{Acknowledgments}

The authors are grateful to PETROBRAS/Cenpes for providing the sediment samples, to Drs. Alberto G. Figueiredo and Renato C. Cordeiro for the granulometric data. National Counsel for Technological and Scinentific Development $(\mathrm{CNPq})$ provided the financial support and a MSc grant to L. Ribeiro and a research fellowship (Proc. No. 304168/2004-1) for R. Carreira. We also thank the two anonymous reviewers whose comments improved the final version of the manuscript.

\section{References}

1. Koelmans, A. A.; Jonker, M. T. O.; Cornelissen, G.; Bucheli, T. D.; Van Noort, P. C. M.; Gustafsson, O.; Chemosphere 2006, 63,365 . 
2. Mannino, A.; Harvey, H. R.; Limnol. Oceanogr. 2004, 49, 735.

3. Dickens, A. F.; Gélinas, Y.; Masiello, C. A.; Wakeham, S.; Hedges, J. I.; Nature 2004, 427.

4. Hammes, K.; Schmidt, M. W. I.; Smernik, R. J.; Currie, L. A.; Ball, W. P.; Nguyen, T. H.; Louchouarn, P.; Houel, S.; Gustafsson, M.; Elmquist, M.; Cornelissen, G.; Skjemstad, J. O.; Masiello, C. A.; Song, J.; Peng, P.; Mitra, S.; Dunn, J. C.; Hatcher. P. G.; Hockaday, W. C.; Smith, D. M.; HartkopfFröder, C.; Böhmer, A.; Lüer, B.; Huebert, B. J.; Amelung, W.; Brodowski, S.; Huang, L.; Zhang, W.; Gschewend, P. M.; Flores-Cervantes, D. X.; Largeau, C.; Rouzaud, J-N.; Rumpel, C.; Guggenberger, G.; Kaiser, K.; Rodionov, A.; Gonzalez-Vila, F. J.; Gonzales-Perez, J. A.; Rosa, J. M.; Manning, D. A. C.; López-Cápel, E.; Ding, L.; Global Biogeochem. Cycles 2007, 21, doi:10.1029/2006GB002914.

5. Cornelissen, G.; Gustafsson, M.; Bucheli, T. D.; Jonker, M. T. O.; Koelmans, A.; Van Noort, P. C. M.; Environ. Sci. Technol. 2005, 39, 6881.

6. Mitra, S.; Bianchi, T. S.; Mckee, B. A.; Sutula, M.; Environ. Sci. Technol. 2002, 36, 2296.

7. Masiello, C. A.; Mar. Chem. 2004, 92, 201.

8. Hedges, J. I.; Eglinton, G.; Hatcher, P. G.; Kirchman, D. L.; Arnosti, C.; Derenne, S.; Evershed, R. P.; Kögel-Knabner, I.; de Leeuw, J.W.; Littke, R.; Michaelis, W.; Rullkötter, J.; Org. Geochem. 2000, 31, 945.

9. Quenea, K.; Derenne, S.; Rumpel, C.; Rouzaud, J.-N.; Gustafsson, O.; Carcaillet, C.; Mariotti, A.; Largeau, C.; Org. Geochem. 2006, 37, 1185; Reddy, C. M.; Pearson, A.; Xu, L.; Mcnichol, A. P.; Benner Jr., B. A.; Wise, S. A.; Klouda, G. A.; Currie, L. A.; Eglinton, T. I.; Environ. Sci. Technol. 2002, 36, 1774.

10. Oen, A. M. P.; Cornelissen, G.; Breedveld, G. D.; Environ. Pollut. 2006, 141, 370.

11. Kim, Y.; Hatsushika, H.; Muskett, R. R.; Yamazaki, K.; Atmos. Environ. 2005, 39, 3513; Highwood, E. J.; Kinnersley, R. P.; Environ. Int. 2006, 32, 560

12. Seixas, T. G.; Moreira, I.; Kehrig, H. D. A.; Malm, O.; Quim. Nova 2007, 30, 554; Limaverde, A. M.; de L. Rebello Wagener, A.; Fernandez, M. A.; de L. Scofield, A.; Coutinho, R.; Mar. Environ. Res. 2007, 64, 384; Francioni, E.; Wagener, A. L. R.; Scofield, A. L.; Depledge, M. H.; Cavalier, B.; Sette, C. B.; Carvalhosa, L.; Lozinsky, C.; Mariath, R.; Sci. Total Environ. 2007, 372, 515; Farias, C. O.; Hamacher, C.; Wagener, A. D. L.
R.; De Campos, R. C.; Godoy, J. M.; J. Braz. Chem. Soc. 2007, 18, 1194; Da Silva, T. F.; Azevedo, D. D. A.; Neto, F. R. D. A.; Environ. Forensics 2007, 8, 257; Da Silva, T. F.; Azevedo, D. D. A.; Neto, F. R. D. A.; J. Braz. Chem. Soc. 2007, 18, 628; Brito, A. P. X.; Brüning, I. M. R. A.; Moreira, I.; Mar. Pollut. Bull. 2002, 44, 79; Guadalupe Meniconi, M. d. F.; Terezinha Gabardo, I.; Rocha Carneiro, M. E.; Maria Barbanti, S.; Cruz da Silva, G.; German Massone, C.; Environ. Forensics 2002, $3,303$.

13. Neto, J.; Gingele, F.; Leipe, T.; Brehme, I.; Environ. Geol. 2006, $49,1051$.

14. Kjerfve, B.; Ribeiro, C. A.; Dias, G. T. M.; Filippo, A.; Quaresma, V. S.; Contin. Shelf Res. 1997, 17, 1609.

15. Wagener, A. L. R.; Quim. Nova 1995, 18, 534.

16. Carreira, R. S.; Wagener, A. L. R.; Fileman, T.; Readman, J.; Macko, S. A.; Veiga, A.; Mar. Chem. 2002, 79, 207.

17. Carreira, R. S.; Wagener, A. L. R.; Readman, J. W.; Estuar. Coast. Shelf Sci. 2004, 60, 587.

18. Feema; Qualidade da água da Baía de Guanabara, Secretaria de Estado de Meio Ambiente, Fundação Estadual de Engenharia do Meio Ambiente: Rio de Janeiro, 1998, pp. 100.

19. Amador, E. S. In Natureza e Sociedade no Rio de Janeiro; Abreu, M. A., ed.; Biblioteca Carioca: Rio de Janeiro, 1992, pp. 201; Quaresma, V. S.; MSc Dissertation, Universidade Federal Fluminense, 1997.

20. Hedges, J. I.; Stern, J. H.; Limnol. Oceanogr. 1984, 29, 657.

21. Gustafsson, O.; Haghseta, F.; Chan, C.; Macfarlane, J.; Gschwend, P. M.; Environ. Sci. Technol. 1997, 31, 203.

22. Godoy, J. M.; Moreira, I.; Bragança, M. J.; Wanderley, C.; Mendes, L. B.; J. Radioanal. Nucl. Chem. 1998, 227, 157.

23. Meyers, P. A.; Chem. Geol. 1994, 114, 289; Macko, S. A.; Engel, M. H.; Parker, P. L. In Organic Geochemistry; Engel, M. H.; Macko, S. A., eds.; Plenum Press: Nova York, 1993, p. 211.

24. Gustafsson, M.; Gschwend, P. M.; Geochim. Cosmochim. Acta 1998, 62, 465.

25. Accardi-Dey, A.; Gschwend, P. M.; Environ. Sci. Technol. 2002, $36,21$.

26. Lima, A. L. C.; PhD Thesis, Massachussetts Institute of Technology, 2004.

27. Rockne, K. J.; Shor, L. M.; Yong, L. Y.; Taghon, G.; Kosson, D.; Environ. Sci. Technol. 2002, 36, 1202.

Received: January 20, 2008 Web Release Date: August 6, 2008 